$\begin{array}{rr}\text { JURNAL } & \text { Volume } 14, \text { Nomor } 1, \text { Januari } 2018 \\ \text { FIT(1) PATOLOGI } & \text { Halaman } 30-38 \\ \text { I N D ON E IA } & \text { DOI: } 10.14692 / \text { jfi.14.1.30 }\end{array}$

\title{
Mikobiota pada Buah Pisang Kultivar Lampung untuk Pengendalian Hayati Fusarium semitectum
}

\section{Mycobiota on Banana Fruits Lampung Cultivar for Biological Control of Fusarium semitectum}

\author{
Okky Setyawati Dharmaputra ${ }^{1,2 *}$, Lisdar Idwan Sudirman', \\ Evarini Anna Ratnaningsih ${ }^{1}$ \\ ${ }^{1}$ Institut Pertanian Bogor, Bogor 16680 \\ ${ }^{2}$ SEAMEO BIOTROP, Bogor 16134
}

\begin{abstract}
ABSTRAK
Fusarium semitectum merupakan cendawan penyebab busuk buah pada pisang. Penggunaan agens hayati merupakan alternatif pengendalian penyakit pascapanen pada buah-buahan. Penelitian ini bertujuan menentukan potensi mikobiota antagonis pada buah pisang (Musa acuminata kultivar Lampung) terhadap F. semitectum BIO 91055. Cendawan uji diisolasi dari buah pisang sehat kultivar Lampung yang diperoleh di pasar Gembrong di Bogor, menggunakan metode pengenceran berseri, dilanjutkan dengan metode cawan tuang. Uji antagonis dilakukan menggunakan metode biakan ganda. Sebanyak 17 isolat cendawan berhasil diisolasi yang terdiri atas 14 isolat cendawan berfilamen dan 3 isolat khamir. Sebanyak 4 isolat cendawan (Aspergillus niger, Cercosporella sp., Plectosphaerella sp., dan Trichoderma hamatum) dapat menghambat pertumbuhan $F$. semitectum BIO 91055 lebih dari 70\%. Tiga isolat cendawan (Cercosporella sp., Plectosphaerella sp., dan T. hamatum) tidak menyebabkan penyakit pada buah pisang sehingga berpotensi untuk dikembangkan sebagai agens hayati.

Kata kunci: antagonis, busuk buah, Cercosporella sp., khamir, Plectosphaerella sp.
\end{abstract}

\begin{abstract}
Fusarium semitectum is a pathogenic fungus causing fruit rot of banana fruits. Biological control agents have been used as an alternative to control postharvest diseases. The objective of this study was to test antagonistic potential of mycobiota of banana fruits (Musa cuminata cultivar Lampung) against F. semitectum BIO 91055. The tested fungi were isolated from healthy banana cultivar Lampung collected from Gembrong market located in Bogor using serial dilution method, followed by pour plate method. Test of antagonism activity was carried out using dual culture method. Seventeen fungal isolates were isolated, they consisted of 14 filamentous fungal isolates and 3 yeast isolates. Four filamentous fungal isolates inhibited the growth of F. semitectum BIO 91055 more than 70\%, they were Aspergillus niger, Cercosporella sp., Plectosphaerella sp., and Trichoderma hamatum. Three isolates (Cercosporella sp., Plectosphaerella sp., and Trichoderma hamatum) did not cause any diseases of banana fruits and they were considered as potential biocontrol agents.
\end{abstract}

Key words: antagonist, Cercosporella sp., fruit rot, Plectosphaerella sp., yeast

*Alamat penulis korespondensi: Departemen Biologi, Fakultas Matematika dan Ilmu Pengetahuan Alam, Institut Pertanian Bogor, Jalan Agatis, Kampus IPB Darmaga, Bogor 16680.

Tel : 0251-8622833, Faks : 0251-8622833, Surel : okky@biotrop.org. 


\section{PENDAHULUAN}

Pada tahun 2014 produksi total pisang di Indonesia mencapai 6862567 ton, dan produksi pisang provinsi Lampung menempati urutan pertama, yaitu sebesar 1481693 ton (BPS 2015). Kendala utama yang mengakibatkan kerugian pascapanen pada buah pisang ialah penyakit busuk buah yang disebabkan oleh Fusarium semitectum (Gambar 1). Di Indonesia informasi kerugian yang diakibatkan oleh $F$. semitectum belum tersedia. Menurut Indrakeerthi dan Adikaram (2011) F. semitectum merupakan salah satu cendawan penyebab utama busuk buah pisang di Sri Lanka.

Pengendalian hayati menggunakan mikrob antagonis merupakan alternatif pengendalian penyakit pascapanen. Lassois et al. (2008) melaporkan bahwa khamir Candida oleophila galur $\mathrm{O}$ dapat mengendalikan $F$. moniliforme, cendawan penyebab busuk mahkota buah pisang. Konidium dan filtrat biakan Trichoderma asperellum dapat mengendalikan busuk buah pisang yang disebabkan oleh $F$. oxysporum (Adebesin et al. 2009). Mekanisme antagonis yang dapat terjadi antarcendawan, yaitu antibiosis dan lisis, kompetisi, dan parasitisme. Tujuan penelitian ini ialah menentukan potensi mikobiota antagonis pada buah pisang terhadap $F$. semitectum .

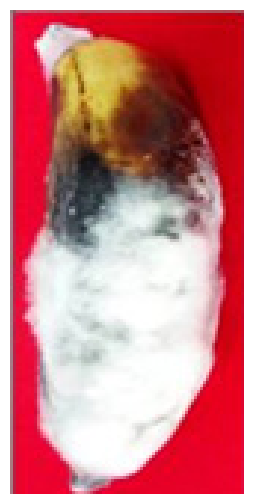

a

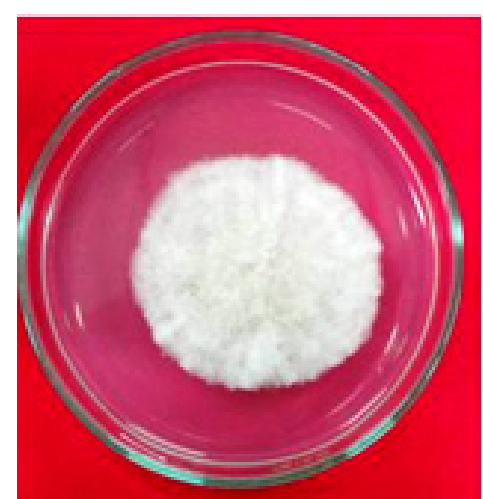

b
Gambar 1 Gejala busuk buah pisang dan karakteristik morfologi Fusarium semitectum BIO 91055. a, Buah pisang kultivar Lampung terserang busuk buah setelah 7 hari inkubasi pada suhu ruang $\left(28 \pm 2{ }^{\circ} \mathrm{C}\right)$; dan b, Koloni pada medium ADK setelah 7 hari inkubasi.

\section{BAHAN DAN METODE}

Buah pisang sehat yang digunakan ialah kultivar Lampung. Buah dari satu tandan diperoleh dari beberapa pasar tradisional di Bogor, yaitu pasar Bogor, pasar Anyar, dan pasar Gembrong. Fusarium semitectum yang digunakan, ialah $F$. semitectum BIO 91055 koleksi SEAMEO BIOTROP, Bogor.

\section{Isolasi Cendawan Uji}

Isolasi mikobiota pada buah pisang sehat dilakukan dengan metode pengenceran berseri yang dilanjutkan dengan metode cawan tuang pada medium agar-agar dekstrosa kentang (ADK) yang mengandung kloramfenikol (100 mg L L ${ }^{-1}$. Sebanyak $100 \mathrm{~g}$ kulit buah pisang dihancurkan menggunakan blender dan ditambahkan akuades steril hingga volumenya $500 \mathrm{~mL}$. Suspensi kulit pisang yang telah dihaluskan kemudian diencerkan secara berseri sehingga didapatkan pengenceran 1:10, 1:20, 1:100, dan 1:1000. Sebanyak $1 \mathrm{~mL}$ suspensi dari setiap pengenceran dituangkan ke dalam cawan petri dan ditambahkan $12 \pm 1 \mathrm{~mL}$ medium ADK $\left(40 \pm 2{ }^{\circ} \mathrm{C}\right)$ yang mengandung kloramfenikol. Setiap pengenceran diulang 3 kali. Cawan petri diinkubasi pada suhu ruang $\left(28 \pm 2{ }^{\circ} \mathrm{C}\right)$ selama 5-7 hari. Pengamatan dilakukan terhadap koloni cendawan yang berbeda warna dan pola pertumbuhannya. Selanjutnya koloni tersebut dimurnikan pada medium ADK tanpa kloramfenikol.

\section{Uji Antagonisme antara Cendawan Uji dan F. semitectum BIO 91055}

Setiap isolat cendawan hasil isolasi dari kulit buah pisang sehat diuji sifat antagonisnya terhadap $F$. semitectum $\mathrm{BIO}$ 91055 menggunakan metode biakan ganda (Skidmore dan Dickinson 1976). Fusarium semitectum BIO 91055 ditumbuhkan secara berpasangan dengan setiap isolat cendawan uji di medium ADK di dalam cawan petri dengan jarak antarisolat $3 \mathrm{~cm}$.

Fusarium semitectum BIO 91055 ditumbuhkan pada tiga waktu inokulasi yang berbeda, yaitu waktu yang sama dengan inokulasi cendawan uji (cendawan berfilamen 
dan khamir), 3 hari setelah inokulasi (HSI) cendawan uji (cendawan berfilamen), dan 7 HSI cendawan uji (kelompok khamir). Perbedaan waktu inokulasi ditentukan berdasarkan pada kecepatan pertumbuhan cendawan berfilamen dan khamir yang tidak sama. Inokulum setiap isolat cendawan dan khamir terdiri atas potongan biakan pada medium ADK berdiameter $5 \mathrm{~mm}$. Setiap perlakuan diulang 3 kali. Selanjutnya masingmasing kelompok cendawan berfilamen dan khamir diinkubasikan pada suhu ruang selama 7 hari. Persentase penghambatan terhadap pertumbuhan $F$. semitectum BIO 91055 oleh cendawan uji dihitung berdasarkan rumus Fokkema (1978), yaitu

$\%$ Penghambatan $=\frac{\left(\mathrm{j}_{1}-\mathrm{j}_{2}\right)}{\mathrm{j}_{1}} \times 100 \%$, dengan

$\mathrm{j}_{1}$, jari-jari koloni $F$. semitectum BIO 91055 yang tumbuh ke arah berlawanan dengan tempat cendawan uji; $\mathrm{j}_{2}$, jari-jari koloni $F$. semitectum BIO 91055 yang tumbuh ke arah tempat cendawan uji.

Cendawan uji yang menyebabkan penghambatan pertumbuhan $F$. semitectum BIO 91055 lebih dari $70 \%$ berpotensi sebagai antagonis. Pengamatan mekanisme antagonisme dilakukan secara makroskopi, yaitu dengan mengamati tipe interaksi antar cendawan (Wheeler dan Hocking 1993).

\section{Uji Patogenisitas Calon Agens Hayati}

Isolat cendawan uji yang menyebabkan hambatan pertumbuhan $F$. semitectum $\mathrm{BIO}$ 91055 lebih dari $70 \%$ diuji patogenisitasnya pada buah pisang kultivar Lampung. Buah pisang yang sehat dengan ukuran dan kematangan yang sama dibilas dengan air dan dikeringanginkan, selanjutnya permukaan buah disterilkan menggunakan etanol $70 \%$. Bagian pangkal dan tengah setiap buah digores vertikal dan horizontal, masing-masing $1 \mathrm{~cm}$. Di atas goresan tersebut diletakkan inokulum berupa potongan koloni dari setiap isolat cendawan antagonis berumur 7 hari berukuran diameter $8 \mathrm{~mm}$. Sebagai kontrol di atas goresan diletakkan potongan medium ADK tanpa $F$. semitectum $\mathrm{BIO}$ 91055, dan pisang yang telah digores tanpa diberi apa pun. Setiap perlakuan (termasuk kontrol) diulang 6 kali. Buah pisang yang telah diinokulasi dimasukkan ke dalam wadah plastik dan diinkubasi pada suhu ruang $\left(28 \pm 2{ }^{\circ} \mathrm{C}\right)$ selama 7 hari. Pengamatan patogenisitas dilakukan terhadap luas permukaan pisang yang terserang setiap isolat cendawan antagonis dengan metode gravimetri, yaitu dengan cara menggambar tepi gejala pada selembar plastik transparan dan mencetak kembali pada karton tebal, kemudian bobot karton (g) tersebut dikonversi ke luas gejala $\left(\mathrm{mm}^{2}\right)$ berdasarkan bobot karton $0.06 \mathrm{~g}$ yang luasnya $100 \mathrm{~mm}^{2}$.

\section{Rancangan Percobaan dan Analisis Data}

Uji antagonis untuk setiap waktu inokulasi F. semitectum yang berbeda dan patogenesitas masing-masing disusun dalam rancangan acak lengkap. Pada uji antagonis antara cendawan uji dengan $F$. semitectum yang dipasangkan pada waktu inokulasi yang berbeda digunakan masing-masing 17, 14, dan 3 taraf. Masingmasing taraf menjelaskan jumlah isolat cendawan uji. Semua analisis statistik dilakukan menggunakan program SPSS versi 16.0. Hasil analisis ragam yang memberikan perbedaan yang nyata dilanjutkan dengan uji Duncan (DMRT).

\section{Identifikasi Cendawan Antagonis yang Berpotensi sebagai Agens Hayati}

Isolat cendawan uji yang menunjukkan daya antagonis dan bukan merupakan patogen pada pisang diindentifikasi secara morfologi mengikuti Rifai (1969), Gams dan Bissett (1998); Barnett dan Hunter (1999); serta Varga dan Samson (2008). Biakan murni setiap cendawan antagonis dibuat preparat menggunakan pewarna laktofenol biru kapas untuk mengamati ciri khusus menggunakan mikroskop. Identifikasi secara molekuler dilakukan di Laboratorium Ina Culture Collection LIPI berdasarkan analisis genetika secara parsial pada sub unit ribosomal DNA daerah D1/D2. Isolasi DNA diawali menggunakan primer NL1(5'CATATCAATAAGCGGAGGAAAG-3') dan NL4 (5'-GTCCGTGTTTCAAGACGG-3’). 
Isolat khamir ditumbuhkan pada medium cair potato dextrose broth (PDB) dan diinkubasi selama 72 jam. Biomassa berupa sel khamir selanjutnya dipanen untuk proses ekstraksi DNA. Ekstraksi DNA dilakukan dengan menggunakan reagen nucleon PHYTOpure (Amersham Life Science).

Purifikasi PCR product dilakukan dengan metode presipitasi polietilenaglikol (PEG precipitation method) (Hiraishi et al. 1995) dan dilanjutkan dengan siklus sikuensing. Hasil sikuensing dipurifikasi kembali dengan metode purifikasi etanol. Analisis pembacaan urutan basa nitrogen menggunakan DNA sekuenser otomatis (ABI PRISM 3130 Genetic Analyzer). Analisis homologi asam amino gen khamir menggunakan basic local alignment search tool (BLAST) pada situs National Center for Biotechnology Information (NCBI) (www.blast.ncbi.nih.gov).

\section{HASIL}

\section{Mikobiota pada Buah Pisang dan} Antagonismenya terhadap $F$. semitectum

Sebanyak 17 mikobiota berhasil diisolasi dari kulit buah pisang sehat, terdiri atas 14 isolat cendawan berfilamen dan 3 isolat khamir (Tabel 1). Hasil uji antagonisme menunjukkan 4 isolat cendawan berfilamen (EAR-10, EAR-15, EAR-20, dan EAR-26) memiliki penghambatan lebih dari $70 \%$ (Tabel 1). Interaksi yang terjadi antara cendawanuji dan $F$. semitectum pada medium ADK menunjukkan empat tipe interaksi, yaitu inhibisi mutual yang ditunjukkan dengan adanya kontak miselium dan terbentuknya zona hambatan kurang dari $2 \mathrm{~mm}$ (tipe B); inhibisi mutual dengan zona hambatan lebih dari $2 \mathrm{~mm}$ (tipe D); inhibisi patogen, sedangkan cendawan uji tetap mengalami pertumbuhan (tipe E), dan tipe $\mathrm{F}$, yang dicirikan dengan cendawan patogen tetap mengalami pertumbuhan melewati cendawan yang diuji (Gambar 2).

\section{Patogenisitas Cendawan Antagonis}

Hasil uji patogenisitas menunjukkan bahwa 3 isolat (EAR-10, EAR-15, dan EAR26) tidak menyebabkan nekrosis pada buah pisang. Isolat EAR-20 menyebabkan penyakit pada buah pisang dengan gejala berupa busuk buah (Tabel 2).

\section{Identifikasi Cendawan Antagonis}

Isolat cendawan uji yang telah ditapis pada uji daya hambatnya mampu menekan pertumbuhan $F$. semitectum lebih dari $70 \%$ dan tidak menimbulkan nekrosis pada uji patogenisitas, yaitu EAR-10, EAR-15, EAR20, dan EAR-26. Cendawan tersebut telah diidentifikasi secara morfologi atau molekuler.

Tiga isolat diidentifikasi secara konvensional karena karakteristik struktur reproduksinya yang khas dapat ditemukan pada medium ADK dan sesuai dengan kunci identifikasi. Isolat EAR-10 teridentifikasi sebagai Cercosporella sp. yang dicirikan dengan konidium hialin, silindris sampai melengkung dan terdiri dari beberapa sel (Gambar 3). Isolat EAR 20 dengan ciri konidiofor tegak dengan pembesaran di bagian ujung, fialid terdapat di ujung konidiofor dan membawa konidium bersel tunggal yang tersusun dalam rangkain memanjang diidentifikasi sebagai Aspergillus niger. Selanjutnya isolat EAR-26 dengan ciri umum adanya konidiofor warna hialin dan bercabang, ada fialid berwarna hialin yang membawa konidium berwarna hijau, tidak berseptum terbentuk di atas fialid teridentifikasi sebagai Trichoderma hamatum (Gambar 4).

Isolat EAR-15 tidak teridentifikasi secara morfologi(Gambar 5). Hasil analisis molekuler terhadap isolat EAR-15, menunjukkan bahwa EAR-15 memiliki homologi 99\% sikuen basa nukleotida dengan beberapa sikuen khamir yang tersedia dalam GenBank antara lain Plectosphaerella sp. MH727, P. citrullae, P. ramiseptata, $P$. plurivora, dan $P$. pauciseptata (Tabel 3). Analisis filogenetik menunjukkan bahwa EAR-15 satu kelompok dengan Plectosphaerella sp. MH727 (Gambar 6).

\section{PEMBAHASAN}

Cendawan uji yang ditumbuhkan terlebih dahulu pada medium ADK saat uji penghambatan pertumbuhan memberi 


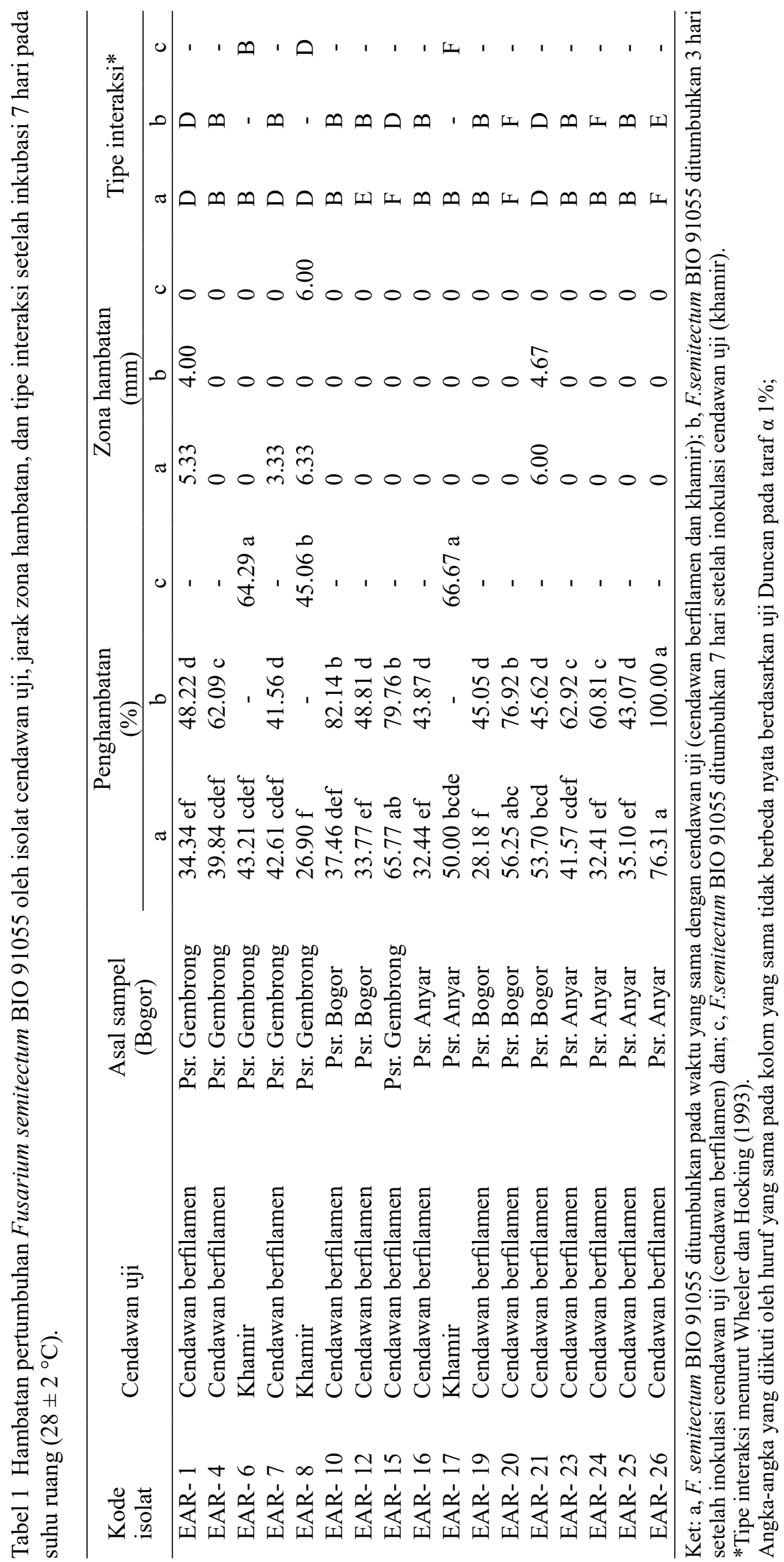




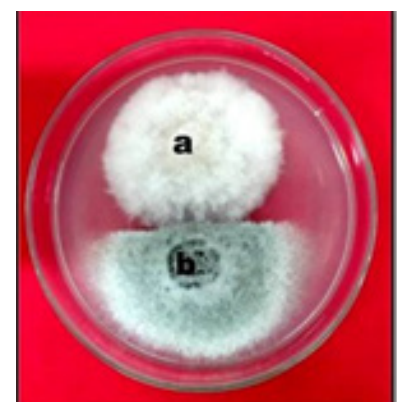

Cercosporella sp. EAR 10

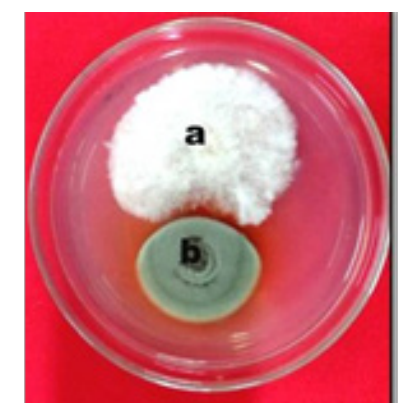

Plectosphaerella sp. EAR 15

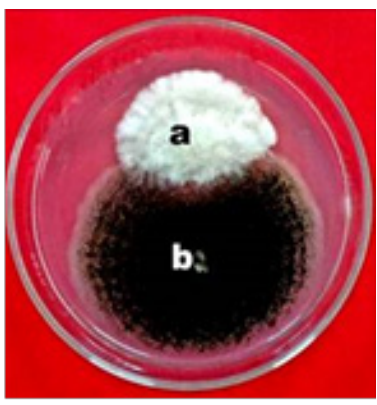

Aspergillus niger EAR 20

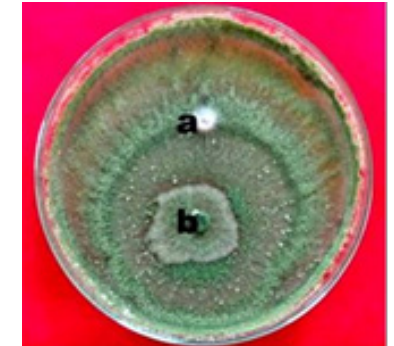

Trichoderma hamatum EAR 26

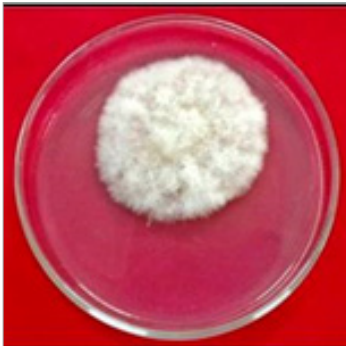

Kontrol

Gambar 2 Uji antagonisme antara Fusarium semitectum BIO 91055 (a) dan empat cendawan uji (b) pada 7 HSI.

Tabel 2 Uji patogenisitas 4 isolat cendawan antagonis pada buah pisang kultivar Lampung

\begin{tabular}{llcc}
\hline Kode isolat & Isolat cendawan uji & $\begin{array}{c}\text { Patogenisitas pada } \\
\text { buah pisang }\end{array}$ & $\begin{array}{c}\text { Luas permukaan gejala penyakit } \\
\left(\mathrm{mm}^{2}\right)\end{array}$ \\
\hline EAR-10 & Cercosporella sp. & - & - \\
EAR-15 & Plectosphaerella sp. & - & - \\
EAR-20 & Aspergillus niger & + & 499.67 \\
EAR-26 & Trichoderma hamatum & - & - \\
& F. semitectum BIO 91055 & + & 329.28 \\
& $\mathrm{~K}_{1}$ & - & - \\
& $\mathrm{K}_{2}$ & - & - \\
\hline
\end{tabular}

+ , menyebabkan penyakit pada buah pisang; -, tidak menyebabkan penyakit pada buah pisang; K1, kontrol 1 (medium agar-agar dekstrosa kentang) tanpa F. semitectum BIO 91055); K2, kontrol 2 (tanpa medium agar-agar dekstrosa kentang tanpa $F$. semitectum BIO 91055).

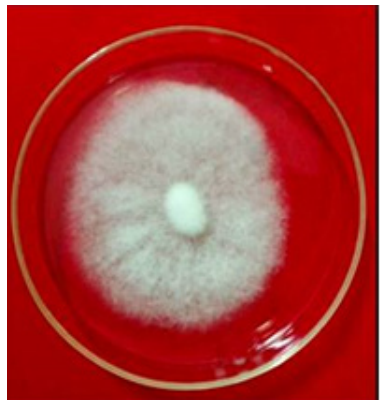

a

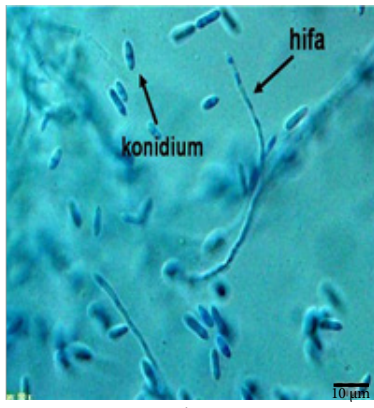

b

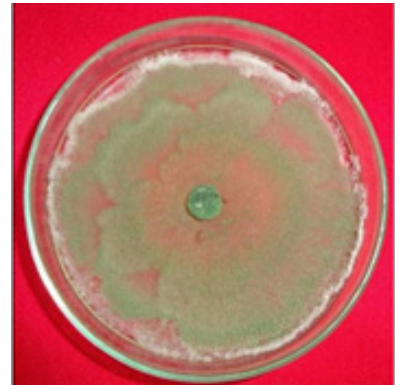

a

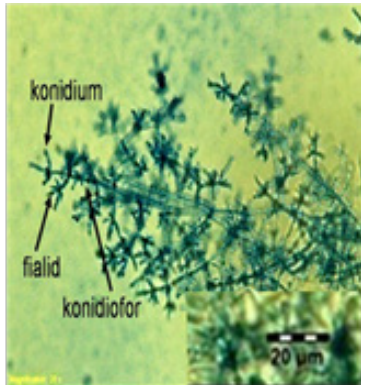

b

Gambar 3 Cercosporella sp. EAR 10. a, Koloni pada medium ADK setelah inkubasi 7 hari pada suhu ruang $\left(28 \pm 2^{\circ} \mathrm{C}\right)$; dan $\mathrm{b}$, Hifa dan konidium.

Gambar 4 Trichoderma hamatum. EAR 26. a, Koloni pada medium ADK setelah inkubasi 7 hari pada suhu ruang $\left(28 \pm 2{ }^{\circ} \mathrm{C}\right)$; dan b, Konidiofor, fialid dan konidium. 
hambatan lebih besar dibandingkan dengan perlakuan yang ditumbuhkan bersamaan. Persentase hambatan pertumbuhan $F$. semitectum BIO 91055 oleh khamir tergolong rendah, yaitu kurang dari $70 \%$, berkisar antara 45.06-66.67\%. Hal tersebut disebabkan oleh pertumbuhankhamirlebihlambatpadamedium ADK dibandingkan $F$. semitectum (cendawan

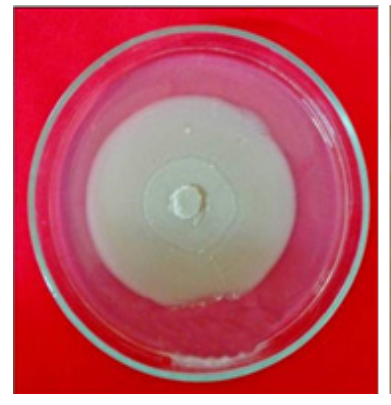

a

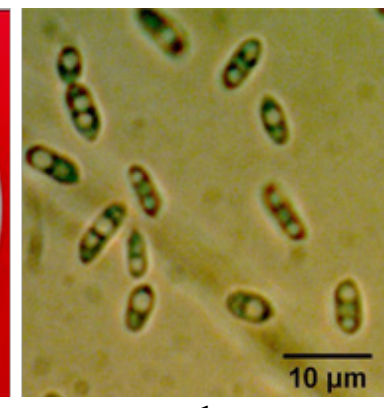

b
Gambar 5 Plectosphaerella sp. EAR 15. a, Koloni pada medium ADK 7 HSI pada suhu ruang $\left(28 \pm 2{ }^{\circ} \mathrm{C}\right)$ dan $\mathrm{b}$, Konidium. berfilamen). Medium ADK tidak menyediakan kondisi optimal untuk khamir yang digunakan menunjukkan potensinya. Menurut ElTarabily dan Sivasithamparam (2006) khamir yang digunakan sebagai agens hayati memiliki mekanisme tertentu dalam menghambat cendawan penyebab penyakit pada buah dan sayuran. Khamir membutuhkan lebih banyak nutrisi untuk menghambat pertumbuhan patogen karena sifatnya mikoparasit (memiliki enzim pendegradasi dinding sel) dan memiliki mekanisme antibiosis. Fitriati et al. (2013) mendapatkan Pichia anomala dan Candida intermedia merupakan jenis khamir yang efektif untuk mengendalikan Colletotrichum sp. penyebab busuk buah alpukat. Daya antibiosis dan produksi enzim kitinase bukan satu-satunya faktor yang menyebabkan khamir berpotensi sebagai agens mengendalikan penyakit, tetapi ada banyak mekanisme lainnya. Candida tropicalis YZ1, Saccharomyces cerevisiae YZ7 dan $C$.

Tabel 3 Homologi sikuen basa nukleotida isolat EAR-15 dengan beberapa sikuen khamir yang tersedia di GenBank

\begin{tabular}{|c|c|c|c|c|c|c|c|c|c|c|c|}
\hline \multirow{2}{*}{ Spesies khamir } & \multirow{2}{*}{ No. Aksesi } & \multicolumn{10}{|c|}{ Tingkat homologi (\%) } \\
\hline & & 1 & 2 & 3 & 4 & 5 & 6 & 7 & 8 & 9 & 10 \\
\hline 1 EAR-15 & 8TWRM3NJ015 & 100 & & & & & & & & & \\
\hline 2 Plectosphaerella citrullae & KY662255.1 & 99 & 100 & & & & & & & & \\
\hline 3 Plectosphaerella citrullae & KY662254.1 & 99 & 99 & 100 & & & & & & & \\
\hline 4 Plectosphaerella ramiseptata & KY662253.1 & 99 & 99 & 99 & 100 & & & & & & \\
\hline 5 Plectosphaerella ramiseptata & KY662252.1 & 99 & 99 & 99 & 99 & 100 & & & & & \\
\hline 6 Plectosphaerella plurivora & KY662248.1 & 99 & 99 & 99 & 99 & 99 & 100 & & & & \\
\hline 7 Plectosphaerella plurivora & KY662249.1 & 99 & 99 & 99 & 99 & 99 & 99 & 100 & & & \\
\hline 8 Plectosphaerella pauciseptata & KY662251.1 & 99 & 99 & 99 & 99 & 99 & 99 & 99 & 100 & & \\
\hline 9 Plectosphaerella pauciseptata & KY662250.1 & 99 & 99 & 99 & 99 & 99 & 99 & 99 & 99 & 100 & \\
\hline 10 Plectosphaerella sp. MH727 & FJ430715.1 & 99 & 99 & 99 & 99 & 99 & 99 & 99 & 99 & 99 & 100 \\
\hline
\end{tabular}

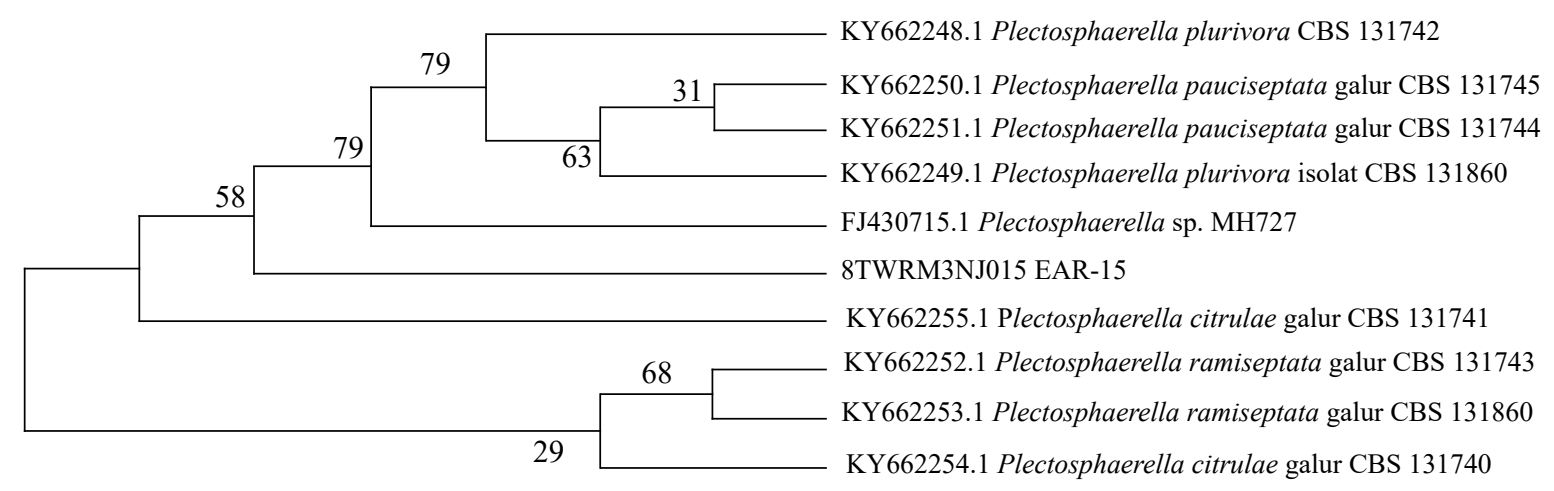

Gambar 6 Pohon filogenetika isolat EAR-15 berdasarkan sikuen nukleotida dan asam amino. 
tropicalis YZ27 dapat mereduksi busuk buah akibat infeksi Colletotrichum musae masingmasing sebesar $85.5 \%, 88.7 \%$ dan $91.9 \%$.

Trichoderma hamatum dapat menghambat pertumbuhan $F$. semitectum BIO 91055 sebesar 76.31\%. Mekanisme penghambatan ini mungkin disebabkan oleh kompetisi ruang dan nutrisi antarcendawan. Trichoderma spp. dapat merusak dinding sel patogen menggunakan enzim hidrolitik dan mampu menghasilkan antibiotik ekstraselular yang menghambat pertumbuhan cendawan patogen (Alvindia dan Natsuaki 2008). Mekanisme mikoparasitisme Trichoderma spp. dimulai dengan pelunakan sel inang oleh enzim yang dihasilkan olehmikoparasit sebelum kerusakan dan kematian sel inang (Papavizas 1985).

Aspergillus niger merupakan salah satu cendawan yang menyebabkan penyakit pada buah-buahan dan sayuran, antara lain buah anggur, bawang, dan kacang tanah; serta menyebabkan kontaminasi pada bahan pangan (Sharma 2012). Menurut Sawant dan Gawai (2011) A. niger merupakan salah satu cendawan yang menyebabkan pematangan buah pisang lebih cepat selama penyimpanan sehingga serangan busuk buah pada pisang terjadi selama masa simpan.

Cercosporella umumnya dijumpai sebagai cendawan penyakit pada banyak jenis tanaman. C. rubi menyebabkan penyakit pada tunas bunga blackberry di Amerika bagian Tenggara (Lyman dan Curry 2004). C. acroptili dan $C$. centaureicola merupakan agens hayati potensial untuk mengendalikan gulma kelompok asteraceae (Berner et al. 2005).

Beberapa spesies Plectosphaerella juga dapat menyebabkan penyakit pada berbagai jenis tanaman hortikultura di Italia (Carlucci et al. 2012). P. cucumeria menyebabkan penyakit busuk akar pada pisang (Kanakala dan Singh 2013), bambu (Arzanlou et al. 2013), dan pada kubis (Li et al. 2017).

Penggunaan Cercosporella sp. dan Plectosphaerella sp. untuk pengendalian hayati $F$. semitectum BIO 91055 perlu dipertimbangkan karena kedua cendawan tersebut dapat menyebabkan penyakit pada tanaman. Trichoderma hamatum adalah cendawan yang berpotensi sebagai agens hayati F. semitectum BIO 91055 pada buah pisang.

\section{UCAPAN TERIMA KASIH}

Ucapan terima kasih penulis sampaikan kepada Direktur SEAMEO BIOTROP atas izin penggunaan sarana dan fasilitas laboratorium Fitopatologi, kepada Ir. Ina Retnowati dan Nijma Nurfadila, S.Si yang telah memberikan beberapa saran; Edi Suryadi yang telah membantu selama penelitian; serta kepada Dr. Atit Kanthi yang membantu mengidentifikasi isolat cendawan EAR-15 secara molekuler.

\section{DAFTAR PUSTAKA}

Adebesin AA, Odebode CA, Ayodele AM. 2009. Control of postharvest rots of banana fruits by conidia and culture filtrates of Trichoderma asperellum. J Plant Protect Res. 49(3):302-308. DOI: https://doi. org/10.2478/v10045-009-0049-6.

Alvindia DG, Natsuaki KT. 2008. Evaluation of fungal epiphytes isolated from banana fruit surfaces for biocontrol of banana crown rot disease. Crop Protect. 27:12001207. DOI: https://doi.org/10.1016/j. cropro.2008.02.007.

Arzanlou M, Torbati M, Khodaei S. 2013. Plectosphaerella cucumerina on bamboo in Iran. Mycopshere. 4(3): 627-631. DOI: https://doi. org/10.5943/mycosphere/4/3/14 10.5943/ mycosphere/4/3/14.

Barnett HL, Hunter BB. 1999. Illustrated Genera of Imperfect Fungi. Ed. ke-8. St. Paul (US): APS Press.

BernerDK, Eskandari FM, BraunU, McMahon MB, Luster DG. 2005. Cerocosporella acroptili and Cercosporella centaureicola nov.-potential biological cotrol agents of Russian knapweed and yellow starthistle, respectively. Mycologia. 97(5): 11221128. DOI: https://doi.org/10.1080/15572 536.2006.11832760. 
[BPS] Badan Pusat Statistik. 2015. Produksi Buah-Buahan Menurut Provinsi http:// www.bps.go.id. [diakses 21 Sept 2015]

Carlucci A, Raimondi ML, Santos J, Phillips AJL. 2012. Plectosphaerella species associated with root and colloar rots of horticultural crops in southern Italy. Persoonia. 28: 34-38. DOI: https://doi. org/10.3767/003158512X638251.

El-Tarabily KA, Sivasithamparam K. 2006. Potential of yeast as biocontrol agents of soil-borne fungal plant pathogens and as plant growth promoters. Mycoscience. 47:25-35. DOI: https://doi.org/10.1007/ S10267-005-0268-2.

Fitriati Y, Wiyono S, Sumarauw IO. 2013. Khamir antagonis untuk pengendalian penyakit antraknosa pada buah alpukat selama penyimpanan. $\mathrm{J}$ Fitopatol Indones. 9(5): 153-159. DOI: https://doi. org/10.14692/jfi.9.5.153.

Fokkema NJ. 1978. Fungal antagonism in the phyllosphere. Ann Appl Biol. 89:115-117. DOI: https://doi. org/10.1111/j.1744-7348.1978.tb02582.x.

Gams W, Bissett J. 1998. Morphology and identification of Trichoderma. Di dalam: Kubicek CP, Harman GE, editor. Trichoderma and Gliocladium. Vol 1. London (GB): Taylor \& Francis Ltd. hlm 3-34.

Hiraishi A, Kamagata Y, Nakamura K. 1995. Polymerasechainreactionamplificationand restriction fragment length polymorphism analysis of $16 \mathrm{~S}$ genes from methanogens. J Fermentation Bioengineering. 79(6):52329. DOI: https://doi.org/10.1016/0922338X(95)94742-A.

Indrakeerthi SRP, Adikaram NKB. 2011. Control of crown rot of banana using Carica papaya latex. J Natn Sci Sri Lanka 39(2):155-162. DOI: https://doi. org/10.4038/jnsfsr.v39i2.3176.

Kanakala S, Singh BP. 2013. Plectosphaerella cucumeria occurences as a new root rot pathogen and p-solubiliser in north-eastern India. Archiev Phytopathol Plant Protect. DOI: https://doi.org/10.1080/03235408.20 13.782674.
Lassois L, Lapeyre de Bellare L, Jijakli MH. 2008. Biological control of crown rot of bananas with Pichia anomala strain $\mathrm{K}$ and Candida oleophila strain O. Biol Control. 45:410-418. DOI: https://doi. org/10.1016/j.biocontrol.2008.01.013.

Li P, Chai A, Shi Y, Xie X, Li B. 2017. First report of root rot caused by Plectosphaerella cucumerina on cabage in China. Mycobiology 45(2): 110113. DOI: https://doi.org/10.1016/j. biocontrol.2008.01.013.

Lyman MR, Curry KJ. 2004. Effect of Cercosporella rubi on blackberry floral bud development. Plant Dis. 88 (2):195204. Publication no. D-2003-1208-04R.

Papavizas GC. 1985. Trichoderma and Gliocladium; Biology, Ecology, and Potential for Biocontrol. Ann Rev Phytopathol. 23:23-54. DOI: https://doi.org/10.1146/annurev. py.23.090185.000323.

Rifai MA. 1969. A revision of the genus Trichoderma. Mycological Paper No. 116. Kew (GB): CMI.

Sawant SG, Gawai DU. 2011. Biochemical changes in banana fruits due to postharvest fungal pathogens. Curr Bot. 2(1):41-42.

Sharma R. 2012. Pathogenicity of Aspergillus niger in plants. Cibtech J Microbiol. $1(1): 47-51$.

Skidmore AM, Dickinson CH. 1976. Colony interactions and hyphal interference between Septoria nodorum and phylloplane fungi. Trans Brit Mycol Soc. 66(1):57-64. DOI: https://doi.org/10.1016/ S0007-1536(76)80092-7.

Varga J, Samson RA. 2008. Aspergillus in the genomic era. Ed ke-1. Wageningen (NL): Wageningen Academic Pub. DOI: https:// doi.org/10.3920/978-90-8686-635-9.

Wheeler KA, Hocking AD. 1993. Interactions among xerophilic fungi associated with dried salted fish. J Appl Bacteriol. 74:164-169. DOI: https://doi. org/10.1111/j.1365-2672.1993.tb03010.x. 